\title{
Grapevine yellows affecting the Croatian indigenous grapevine cultivar Grk
}

\author{
Marin Ježić ${ }^{1}$, Jasminka Karoglan Kontić ${ }^{2}$, Darko Preiner ${ }^{2}$, Edi Maletić ${ }^{2}$, \\ Mirna ĆURKOVIĆ-PERICA ${ }^{1 *}$ \\ ${ }^{1}$ University of Zagreb, Faculty of Science, Division of Biology, Department of Microbio- \\ logy, Marulicev trg 9a, Zagreb, Croatia \\ ${ }^{2}$ University of Zagreb, Faculty of Agriculture, Department of Viticulture and Enology, \\ Svetosimunska 25, Zagreb, Croatia
}

\begin{abstract}
The grapevine cultivar Grk, a close relative of Crljenak kaštelanski/Zinfandel, is grown exclusively in southern Croatia. Grapevine yellows-like symptoms were observed on vines in the vineyards in Lumbarda (southern Croatia) and in propagated grapevines near Zadar and Zagreb. The majority of the detected phytoplasma isolates belonged to the $16 \mathrm{SrI}$ group. However, RFLP pattern and R16F2n/R2 fragment sequence assigned one isolate to the 16SrIII group. Thus far, on cv. Grk, phytoplasmas belonging to three different groups have been detected: $16 \mathrm{SrI}, 16 \mathrm{SrIII}$, and $16 \mathrm{SrXII}$, which was confirmed previously. Aside from the $16 \mathrm{SrI}, 16 \mathrm{SrV}$ and $16 \mathrm{SrXII}$ phytoplasma groups previously found on grapevines in Croatia, the finding of 16SrIII group, which is not common on grapevines in Europe, adds to the diversity of phytoplasmas in a very small geographic region.
\end{abstract}

Key words: molecular detection, phytoplasma, RFLP, Vitis vinifera $\mathrm{cv}$. Grk

\section{Introduction}

Grk is an old Croatian grapevine cultivar grown almost exclusively on the island of Korčula. Its name (Grk in Croatian language means Greek) and long cultivation suggests that the cultivar was brought from the east at the time of the Greek colonization of the island ( $4^{\text {th }}$ century BC). However, because of its close genetic relationship with Crljenak kaštelanski/Zinfandel (as parent and progeny, respectively), and thus its relationship with a group of Dalmatian cultivars (PEJIĆ et al. 2000, MALETiĆ et al. 2004), it is most probable that cv. Grk arose in this area. The population of cv. Grk is rather small and the most productive vineyards are located on sandy soils near the town of Lumbarda, where its grape achieves the highest quality and gives the famous wine quality.

* Corresponding author, e-mail: mirna.curkovic-perica@biol.pmf.hr Copyright $^{\circledR} 2013$ by Acta Botanica Croatica, the Faculty of Science, University of Zagreb. All rights reserved. 
In recent years a decrease in the productive potential of cv. Grk vines in Lumbarda region has been observed. Symptoms like leaf folding, yellowing and drying long before the fall, poor fruit set (cv. Grk has female flowers) and yield lowering indicates either a physiological or a phytosanitary disorder of the vines.

Thus, the cv. Grk population has been screened for the economically most important viruses: Grapevine fanleaf virus (GFLV), Arabis mosaic virus (ArMV), Grapevine leafroll-associated virus 1 (GLRaV-1) and Grapevine leafroll-associated virus 3 (GLRaV-3). Using ELISA, testing of viruses was carried on 70 selected vines from five vineyards more than 15 years old, out of which 37 vines were free of the tested viruses (PREINER et al. 2010). These selected mother stocks of cv. Grk, were propagated and planted in a mother vineyard in Baštica near Zadar in year 2008 for further propagation and clonal selection. The obtained results have shown that infection of the cv. Grk population with those grapevine-associated viruses tested for is much lower than the average for grapevine cultivars in Dalmatia,which reaches about $90 \%$ of virus-infected vines (KAROGLAN KonTIĆ et al. 2009). This indicated that there had to be some other cause of the symptoms observed in Lumbarda vineyards.

One of the possible causes for the decline of the Lumbarda vineyards might be phloem-restricted prokaryotes called phytoplasmas. Phytoplasmas are classified by their $16 \mathrm{~S}$ ribosomal gene into less then 20 clusters (MONTANO et al. 2001, IRPCM 2004, BERTACCINI and DUDUK 2009). Infected grapevines develop very characteristic symptoms - leafyellowing and curling, aborted clusters or shriveling berries, incomplete lignification of shoots, as well as vein necrosis (CONSTABLE 2010). Diseases known as »grapevine yellows « are caused by phytoplasmas from the groups 16SrI-B (aster yellows), 16SrI-C (clover phyllody), 16Sr-II (peanut witches' broom), 16SrIII (X-disease), 16SrV-C and 16SrV-D (elm yellows) and 16SrXII-A and 16SrXII-B (stolbur) (FIRRAO et al. 2005).

Studies of grapevine yellows started in Croatia in the 1950s (PANJAN 1957), but the first molecular confirmation of the causal agent of the disease - phytoplasma - came later with ŠARIĆ et al. (1997). Since then, a few studies on phytoplasma occurrence on grapevine in Croatian vineyards have been conducted (ŠERUGA et al. 2000; ŠERUGA Musić et al. 2009, 2011a, b; ŠKORIĆ et al. 1998, 2011), but only one of them included the testing of one indigenous cv. Grk vine from Lumbarda in Korčula (MiKEC et al. 2006).

The aim of this research was (i) to confirm phytoplasmas as the causal agent of the grapevine yellows-like symptoms on cv. Grk vines, (ii) to determine the disease prevalence at three locations where this cultivar is planted in Croatia and (iii) to determine the diversity of the suspected pathogen (phytoplasmas).

\section{Materials and methods}

Samples of leaf main veins were collected in late summer of 2010 at three locations in Croatia where Grk grapevines can be found: production vineyards in Lumbarda on island Korčula with 10,023 plants, the National Grapevine Collection in Jazbina near Zagreb (six plants) and a mother vineyard in Baštica near Zadar (400 plants) (Fig. 1). The disease symptoms were assessed on site and samples for further analysis chosen accordingly: from 11 plants with pronounced symptoms in Lumbarda and five plants with mild symptoms in Baštica. Only two plants showed mild symptoms in Jazbina, while the rest were asymptom- 


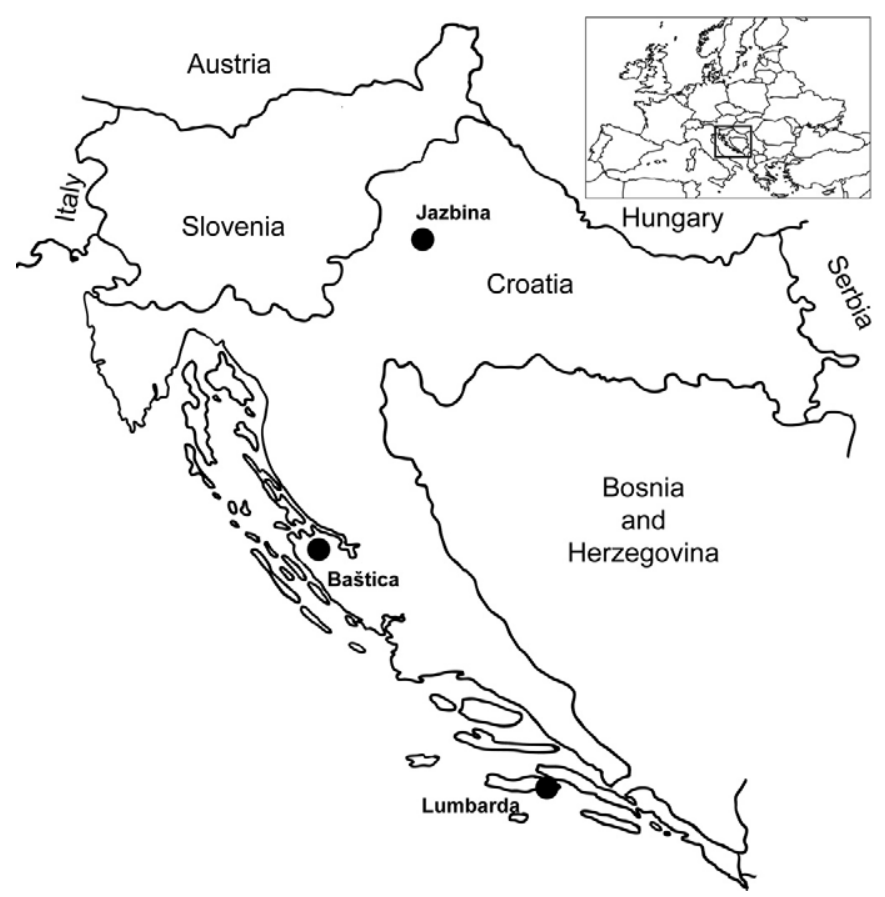

Fig. 1. Geographical locations in Croatia from which the grapevine samples were collected.

atic. Therefore, in that location, the three asymptomatic plants were also included in the analysis.

The procedure for total nucleic acid extraction was performed as previously described by ŠERUGA et al. (2003). DNA concentration was determined using NanoDrop (Themo Fisher Scientific 2000) and adjusted to $20 \mathrm{ng} \mu \mathrm{L}^{-1}$ for the polymerase chain reaction (PCR). Direct amplification of phytoplasma $16 \mathrm{~S}$ rDNA, was performed with a R16F1/R0 primer pair (LEE et al. 1995), and was followed by nested PCR assay, utilizing a R16F2n/R2 primer pair (GUNDERSEN and LEE 1996) with $0.5 \mu \mathrm{L}$ from the first PCR reaction used as a template (making the template $50 \mathrm{x}$ diluted in the nested PCR reaction mixture). In all experiments positive (DNA isolated from various phytoplasma strains maintained in Catharanthus roseus grown in vitro) as well as negative (water and healthy $C$. roseus DNA isolate) controls were used. Approximately $5 \mu \mathrm{L}$ of PCR mixture were analyzed on $1 \%$ agarose gel, stained with ethidium bromide and visualized with UV. All experiments were done in triplicates.

Restriction fragment length polymorphism (RFLP) analysis was performed on R16 F2n/R2 primer pair obtained amplicons. Besides isolates from Lumbarda, Baštica and Jazbina, reference strains of phytoplasmas (maintained in C. roseus plants) were included in RFLP analysis: HYDB ('Candidatus Phytoplasma asteris', 16SrI-B), KVI (Peach X disease, 16SrIII-B), FD (Flavescence dorée, 16SrV-C), GSFY/2 ('Ca. P. prunorum', 16SrX-B), SA-1 (Stolbur, 16SrXII-A). Using restriction endonucleases MseI, AluI and KpnI, digestion was performed on $200 \mathrm{ng}$ of DNA according to manufacturer instructions (Fermentas, Vilnius, Lithuania) and $10 \mu \mathrm{L}$ of reaction mixture was loaded on $5 \%$ polyacrilamide gel electropho- 
Ježić M., Karoglan Kontić J., Preiner D., Maletić E., Ćurković-Perica M.

resis (PAGE) vertical gels. Ethidium bromide-stained gels were photographed and restriction fragment patterns of phytoplasma isolates from cv. Grk were compared with patterns of standard phytoplasma strains.

Amplicon (obtained with R16F2n/R2 primer pair) from sample 02L was sequenced using Macrogen DNA sequencing service (Macrogen, Amsterdam, Netherlands).

\section{Results}

In Lumbarda on Korčula, 79\% of 10,023 vines showed pronounced disease symptoms while $11 \%$ had mild symptoms. The rest of the vines were asymptomatic. The vineyard in Baštica near Zadar is much smaller, and only mild grapevine yellows symptoms were observed on eight out of 400 plants. In a vineyard in Jazbina near Zagreb, which serves as the national collection of grapevine cultivars, only six cv. Grk vines are grown and mild symptoms were observed on two vines.

Tab. 1. Detection of phytoplasmas belonging to two different ribosomal groups in cv. 'Grk' samples collected from three locations in Croatia and expressing different symptom intensity. Pronounced symptoms are indicated with $(++)$, mild symptoms with $(+)$ and symptomless grapevines with (-) in the third column. Fourth and fifth column indicate presence or absence of specific amplicon revealed by agarose gel electrophoresis after the direct and nested PCR.

\begin{tabular}{|c|c|c|c|c|c|}
\hline Location & Sample & Symptoms & $\begin{array}{l}\text { Direct PCR } \\
\text { R16F1/R0 }\end{array}$ & $\begin{array}{l}\text { Nested PCR } \\
\text { R16F2n/R2 }\end{array}$ & $\begin{array}{l}\text { Phytoplasma } \\
\text { ribosomal group }\end{array}$ \\
\hline \multirow{11}{*}{$\begin{array}{l}\text { Lumbarda } \\
\text { (Korčula) }\end{array}$} & $01 \mathrm{~L}$ & ++ & - & + & $16 \mathrm{SrI}$ \\
\hline & $02 \mathrm{~L}$ & ++ & - & + & 16SrIII \\
\hline & $23 \mathrm{~L}$ & ++ & - & + & $16 \mathrm{SrI}$ \\
\hline & 04L & ++ & - & + & $16 \mathrm{SrI}$ \\
\hline & $05 \mathrm{~L}$ & ++ & - & + & $16 \mathrm{SrI}$ \\
\hline & 06L & ++ & - & + & $16 \mathrm{SrI}$ \\
\hline & $07 \mathrm{~L}$ & ++ & - & + & $16 \mathrm{SrI}$ \\
\hline & 08L & ++ & - & + & $16 \mathrm{SrI}$ \\
\hline & 09L & ++ & - & + & $16 \mathrm{SrI}$ \\
\hline & $10 \mathrm{~L}$ & ++ & - & + & $16 \mathrm{SrI}$ \\
\hline & $11 \mathrm{~L}$ & ++ & - & + & $16 \mathrm{SrI}$ \\
\hline \multirow{5}{*}{$\begin{array}{l}\text { Jazbina } \\
\text { (Zagreb) }\end{array}$} & $1 \mathrm{~J}$ & + & - & + & $16 \mathrm{SrI}$ \\
\hline & $2 \mathrm{~J}$ & + & - & + & $16 \mathrm{SrI}$ \\
\hline & $3 \mathrm{~J}$ & - & - & + & $16 \mathrm{SrI}$ \\
\hline & $4 \mathrm{~J}$ & - & - & + & $16 \mathrm{SrI}$ \\
\hline & $5 \mathrm{~J}$ & - & - & + & $16 \mathrm{SrI}$ \\
\hline \multirow{5}{*}{$\begin{array}{l}\text { Baštica } \\
\text { (Zadar) }\end{array}$} & 170 & + & - & + & $16 \mathrm{SrI}$ \\
\hline & 289 & + & - & + & $16 \mathrm{SrI}$ \\
\hline & 290 & + & - & + & $16 \mathrm{SrI}$ \\
\hline & 369 & + & - & + & $16 \mathrm{SrI}$ \\
\hline & 370 & + & - & - & N/A \\
\hline
\end{tabular}


In the direct PCR, only positive controls produced visible amplicons and therefore nested PCR was performed yielding 20 positive samples out of 21 tested. DNA fragments of expected length $(1.2 \mathrm{~kb})$ were obtained. In all our experiments, only one sample from Baštica was consistently negative, despite the mild grapevine yellows-like symptoms observed on that tested vine. On the other hand, phytoplasma was detected in 3 asymptomatic vines from Jazbina (Tab. 1).

In RFLP analysis we digested all DNA products obtained from the first nested PCR. All RFLP patterns were consistent with 16 SrI phytoplasma group, except for sample 02L (Lumbarda) which had a 16SrIII-like pattern (Fig. 2). The partial sequence obtained for that sample (JQ046414) was very similar to the Italian 16SrIII-B group phytoplasma 16SrDNA sequence available in the database (HQ589194) with only one nucleotide mismatch. There were four nucleotide mismatches between our 16SrDNA sequence and the sequence of an isolate belonging to16SrIII from the USA (AF060875) (DAVIS et al. 1998).

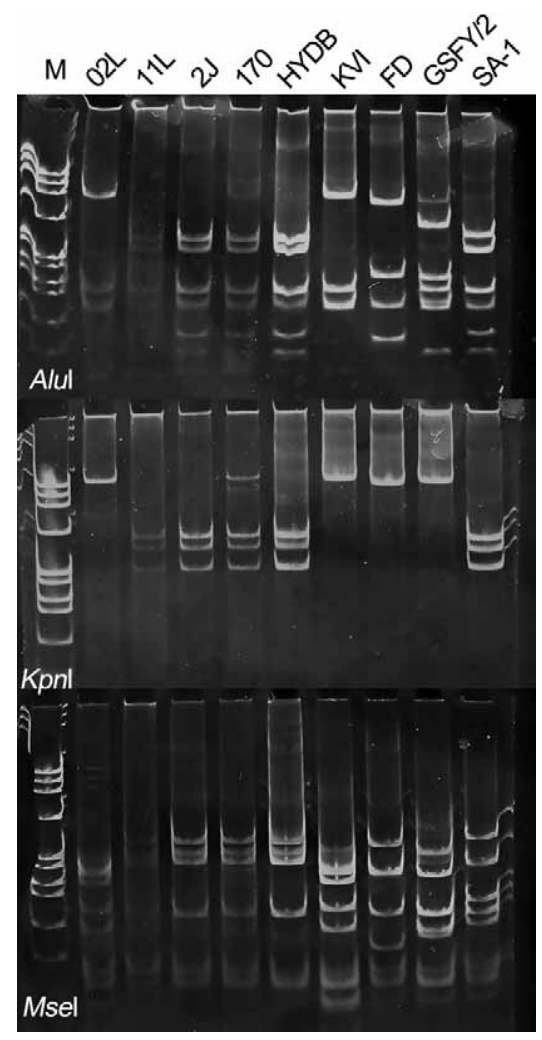

Fig. 2. Restriction fragment length polymorphism patterns of phytoplasmas detected in Croatian vineyards with additional five standard strains as references. Amplicons obtained with R16F2n/R2 were digested with $A l u \mathrm{I}, K p n \mathrm{I}$ and $M s e \mathrm{I}$ restriction enzymes over night and analyzed on 5\% polyacrylamide gels. Marker $\varphi$ X174 HaeIII digest. Samples: 02L and 11L (Lumbarda), 2J (Jazbina), 170 (Baštica); reference strains: HYDB ('Candidatus Phytoplasma asteris', 16SrI-B), KVI (Peach X disease, 16SrIII-B), FD (Flavescence dorée, 16SrV-C), GSFY/2 ('Ca. P. prunorum', 16SrX-B), SA-1 (Stolbur, 16SrXII-A). 
Ježić M., Karoglan Kontić J., Preiner D., Maletić E., Ćurković-Perica M.

\section{Discussion}

Phytoplasmas were detected in all locations included in our study, in plants with pronounced and also in plants without any visible disease symptoms. In samples from Lumbarda, pronounced symptoms, observed on $79 \%$ of the cv. Grk vines, were unambiguously connected with phytoplasma infection. Such prevalence of the disease on a high number of vines might lead to wine production from this particular cultivar in southern Croatia becoming inefficient. Even more, in the tested vines sampled from two other locations, the same phytoplasma was detected even in asymptomatic or vines with only mild grapevine yellows-like symptoms.

This is the first study of the prevalence of phytoplasmoses on the grapevine cv. Grk after the initial report of one vine of this cultivar sampled in Lumbarda, which was infected by phytoplasma from 16SrXII group (MIKEC et al. 2006). Infections of grapevines with phytoplasmas belonging to three groups $16 \mathrm{SrXII}, 16 \mathrm{SrI}$ and $16 \mathrm{SrV}$ were reported in Croatia previously (Mikec et al. 2006; ŠERUGA et al. 2000; ŠERUGA Musić et al. 2009, 2011a, b; ŠKORIĆ et al. 1998, 2011). Phytoplasma belonging to group $16 \mathrm{SrV}$ was detected recently in two vineyards in north-western continental Croatia, near the Slovenian-Croatian border (ŠERUGA Musić et al. 2011b); 16SrXII was found to be widely distributed, in both continental and littoral Croatia while 16SrI was detected only sporadically, mostly in southern Croatia (MikeC et al. 2006), the geographical origin of cv. Grk vines. Phytoplasmas from this group were reported previously on some other grapevine cultivars in southern littoral Croatia, namely in Čara on island of Korčula and on the nearby Pelješac peninsula (MIKEC et al. 2006), but neither in northern Dalmatia (where our samples from Baštica were collected) nor in Jazbina near Zagreb. Therefore it is an interesting finding that all tested cv. Grk vines from three locations were infected by the phytoplasma belonging to the 16SrI group. Since grapevines from Lumbarda were transplanted to Baštica near Zadar and Jazbina near Zagreb for enological studies, there is a high possibility that grapevines were infected before they were transplanted. Another possibility is a novel infection of Grk cultivar grapevines, initiated by insect vectors in our research areas. However, in that case infections by the much more widespread 16SrXII group phytoplasma would be more probable. Yet in Jazbina in continental Croatia where infections by phytoplasmas belonging to 16SrXII were previously repeatedly confirmed on other cultivars (ŠERUGA 2003, ŠERUGA et al. 2000, ŠERUGA Musić et al. 2009), on cv. Grk only phytoplasma belonging to 16SrI group was found.

RFLP pattern and sequence of R16F2n/R2 obtained amplicon of one sample affiliated that phytoplasma to a distinctive 16SrIII phytoplasma group, rather rare and uncommon on grapevine in Europe. Phytoplasmas from this group were found to infect grapevines in USA, Israel and Northern Italy (MuSETTI 2008). Phytoplasma belonging to 16SrIII group was found previously in Croatia on a weed plant - Chenopodium album near Drniš (ŠERUGA 2003), but this is the first report on Vitis vinifera infected with phytoplasma belonging to this particular group. This phytoplasma was found in a single grapevine only in southern Croatia, on a geographically small and isolated area.

Phytoplasmas that belong to ribosomal groups $16 \mathrm{SrI}$ and $16 \mathrm{SrIII}$ infect a broad range of plant hosts. Therefore, there is a high probability that other plant species in Croatia might be infected with these phytoplasmas as well. 


\section{Conclusion}

This study has shown an unusually high prevalence of the 16SrI group phytoplasma on cv. Grk in all three geographically distant locations where it is planted. This oddity is especially prominent in plants transplanted to the continental Croatia where phytoplasmas belonging to the 16SrXII group are well established and widespread in vineyards. We also report on the first occurrence of the 16SrIII group phytoplasma, rather uncommon in European grapevines. Thus far phytoplasmas belonging to three ribosomal groups (16SrI, $16 \mathrm{SrIII}$ and $16 \mathrm{SrXII}$ ) were detected on cv. Grk, increasing the total number of phytoplasma groups detected in Croatian vineyards to four (16SrI, $16 \mathrm{SrIII}, 16 \mathrm{SrV}$ and $16 \mathrm{SrXII})$.

\section{Acknowledgement}

This research was supported by Croatian Ministry of Science Education and Sport, projects no. 119-1191192-1215 and 178-1781844-2758.

\section{References}

BertaccinI, A., Duduk, B. 2009: Phytoplasma and phytoplasma diseases: a review of recent research. Phytopatologia Mediterranea 48, 355-378.

Constable, F. E., 2010: Phytoplasma epidemiology: grapevines as a model. In: WeinTRAUB, P. G., JONES P. (eds), Phytoplasmas: genomes, plant hosts and vectors, 188-212. CABI, Oxfordshire.

Davis, R. E., Jomantiene, R., Dally, E. L., Wolf, T. K., 1998: Phytoplasmas associated with grapevine yellows in Virginia belong to group 16SrI, subgroup A (tomato big bud phytoplasma subgroup), and group 16SrIII, new subgroup I. Vitis 37, 131-137.

GundERSEn, D. E., LeE, I. M., 1996: Ultrasensitive detection of phytoplasmas by nested-PCR assays using two universal primer pairs. Phytopathologia Mediterranea 35, $144-151$.

Firrao, G., GibB, K., Streten, C., 2005: Short taxonomic guide to the genus 'Candidatus Phytoplasma'. Journal of Plant Pathology 87, 249-263.

IRPCM Phytoplasma/Spyroplasma Working Team-Phytoplasma Taxonomy group, 2004: 'Candidatus Phytoplasma', a taxon for the wall-less, non-helical prokaryotes that colonize plant phloem and insects. International Journal of Systematic and Evolutionary Microbiology 54, 1243-1255.

Karoglan Kontić, J., Preiner, D., Šimon, S., Zdunić, G., Poljuha, D., Maletić, E., 2009: Sanitary status of Croatian native grapevine varieties. Agriculturae Conspectus Scientificus $74,1-5$.

LeE, I. M., BertaccinI, A., Vibio, M., Gundersen, D. E., 1995: Detection of multiple phytoplasmas in perennial fruit trees with decline symptoms in Italy. Phytopathology 85, 728-735.

Maletić, E., Pejić, I., Karoglan Kontić, J., Piljac, J., Dangl, G. S., Vokurka, A., Lacombe, T., MirošEvić, N., Meredith, C. P., 2004: Zinfandel, Dobričić and Plavac mali: the genetic relationship among three cultivars of the Dalmatian coast of Croatia. American Journal of Enology and Viticulture 55, 174-180. 
Ježić M., Karoglan Kontić J., Preiner D., Maletić E., Ćurković-Perica M.

MiKeC, I., KrIŽANAC, I., BudinŠČAK, Ž., ŠERUGA Musić, M., KrAJAČIĆ, M., ŠKORIĆ, D., 2006: Phytoplasmas and their potential vectors in vineyards of indigenous Croatian varietis. Extended Abstract 15 Meeting of the International Council for the Study of Virus and Virus-like Diseases of the Grapevine (ICVG), Stellenbosch (South Africa), 255-257.

Montano, H. G., Davis, R. E., Dally, E. L., Hogenhout, S., Pimetal, J. P., Brioso, P. S. T., 2001: 'Candidatus Phytoplasma brasiliense', a new phytoplasma taxon associated with hibiscus witches' broom disease. International Journal of Systematic and Evolutionary Microbiology 51, 1109-1118.

MusEtTI, R., 2008: Managment and ecology of phytoplasma diseases of grapevine and fruit crops. In: Cianciao, A., MukerJi, K. G., (eds.), Integrated management of diseases caused by fungi, phytoplasma and bacteria, 43-60. Springer.

PANJAn, M., 1957: Stolbur virus. Glasnik Zaštite Bilja 5, 51-54.

Pejić, I., MirošEvić, N., Maletić, E., Piluac, J., Carole, P. M., 2000: Relatedness of cultivars Plavac mali, Zinfandel and Primitivo (Vitis vinifera L.). Agriculturae Conspectus Scientificus 65, 21-25.

Preiner, D., Cibilić, I., Karoglan Kontić, J., Marković, Z., Maletić, E., 2010: Effect of Grapevine leafroll associated virus 3 on ampelographic characteristics of cv. Grk (Vitis vinifera L.). Proceedings 45 Croatian and 5 International Symposium on Agriculture, Osijek (Croatia), 1188-1192.

ŠArić, A., ŠKorić, D., Bertaccini, A., Vibio, M., Murari, E., 1997: Molecular detection of phytoplasmas infecting grapevines in Slovenia and Croatia. Proceedings 12 Meeting ICVG, Lisabon, 77-78.

ŠERUGA, M., 2003: Molecular detection and identification of phytoplasmas in Croatian Grapevines (Vitis vinifera L.) (in Croatian with English Summary). MSc Thesis, University of Zagreb, Zagreb.

Š́ruga, M., Ćurković-Perica, M., ŠKorić, D., Kozina, B., MirošEvić, N., ŠArić, A., BERTACCINI, A., KRAJAČIĆ, M., 2000: Geographic distribution of Bois Noir phytoplasma infecting grapevines in Croatia. Journal of Phytopathology 148, 239-242.

Š́ruga, M., ŠKorić, D., Kozina, B., Mitrev, S., KrajaČić, M., Ćurković Perica, M., 2003: Molecular identification of a phytoplasma infecting grapevine in the republic of Macedonia. Vitis 42, 181-184.

ŠEruga Musić, M., ŠKorić, D., BudinšČAK, Ž., KriŽAnac, I., MikeC, I., 2009: Survey of phytoplasma diversity in heavily grapevine yellows affected areas of Croatia. Le Progres Agricole et Viticole Hors Serie, 206-207.

ŠEruga Musić, M., PuŠIć, P., FABRe, A., ŠKorić, D., FoISSAC, X., 2011a: Variability of stolbur phytoplasma strains infecting Croatian grapevine by multilocus sequence typing. Bulletin of Insectology 64, 39-40.

Šeruga Musić, M., ŠKorić, D., HalušKa, I., KrižAnac, I., Plavec, J., MiKec, I., 2011b: First report of flavescence dorée -related phytoplasma affecting grapevines in Croatia. Plant Disease 95, 353-353.

ŠKorić, D., ŠArić, A., Vibio, M., Murari, E., KrajaČIĆ, M., BERTACCINI, A., 1998: Molecular identification and seasonal monitoring of phytoplasmas infecting Croatian grapevines. Vitis 37, 171-175.

ŠKorić, D., ŠERUga Musić, M., PlaVEC. J., KriŽAnAC, I., 2011: Geographical distribution of 'flavescence dorée' phytoplasmas in Croatian grapevines. Bulettin of Insectology 64, 243-244. 